\title{
WANSBROUGH DAN ISLAMIC STUDIES
}

Oleh: Laila Ngindana Zulfa

\begin{abstract}
Abstrak
Gagasan bahwa Yahudi dan Kristen merupakan agama “dalam sejarah” umumnya telah diterima oleh banyak kalangan. Oleh sebab itu para sarjanawan modern mencoba mendekati Islam seperti halnya kedua agama tersebut dikarenakan ketiga Agama ini memiliki kemiripan dalam segi ajaran Agama. Relevansi dari asumsi ini menggiring untuk bersikap sama terhadap sumber-sumber yang tersedia dalam kajian Islam pada masa awal, sebagaimana gambaran sikap terhadap keduanya. Dari sumber tersebut, akan didapatkan rekaman atau data-data yang mendukung untuk menganalisa apa yang sesungguhnya terjadi dalam sejarah. Hal ini penting untuk menemukan kebenaran ataupun kepalsuan dari agama tersebut. John Wansbrough merupakan pakar sejarah dari Amerika yang yang mengabdikan dirinya untuk mengajar di Universitas London. Ia dikenal sebagai sarjana Yahudi yang sangat antusias dalam kajian ketimuran dan Afrika di Universitas tempat ia mengajar.
\end{abstract}

Kata kunci: Hakikat sumber, wacana metodologi

\section{Abstract}

The idea that Judaism and Christians is a religion "in history" has been generally accepted by many people. Therefore, modern scholars try to approach Islam as do the two religions because of this religion has similarities in terms of religious teachings. The relevance of this assumption leads to be equal to the resources available in Islamic studies in the early days, as the description attitude towards both of them. From these sources, we will get a recording or data that support to analyze what actually happened in history. It is important to find the truth or falsity of the religion. John Wansbrough is an expert on the history of Americans who devoted himself to teaching at the University of London. He is known as a very enthusiastic Judaism scholar in oriental and African studies at the university where he taught.

Key words: Nature of the source, discourse methodology 


\section{A. Pendahuluan}

Islam sebagai agama yang paling terakhir muncul dimuka bumi ini merupakan agama penyempurna dari agama sebelumnya dan merupakan agama yang dibawa oleh nabi Muhammad SAW, nampaknya belum cukup untuk langsung dipercayai oleh semua umat. Terutama bagi pemeluk Nasrani dan Yahudi yang hampir mempunyai kemiripan dalam tuntunan-tuntunan kehidupan keagamaan yang tertulis dalam kitab masing-masing. Sejumlah peneliti baik dari kalangan umat Islam sendiri maupun diluar Islam yang mencoba meneliti tentang Islam sebagai agama. Melalui berbagai teori yang telah diterapkan dalam studi keagamaan, Islampun tidak luput dari penelitian tersebut.

Berdasar dari pendekatan historis, gagasan mengenai Yahudi dan Kristen merupakan agama-agama dalam sejarah, telah diterima oleh manusia sampai sekarang. Terhadap gagasan ini Andrew Rippin mengemukakan sebuah pertanyaan; "apa yang sesungguhnya terjadi?" Hal ini dirasa penting untuk menemukan kebenaran ataupun kepalsuan dari kedua agama tersebut. Penelitian ini membutuhkan data-data yang mendukung terutama tentang kitab suci, untuk menjelaskan pondasi-pondasi historis agama yang ada. ${ }^{1}$

Para ilmuan modern juga melakukan hal yang sama terhadap agama Islam, Islam didekati dengan cara yang sama, sebagaimana mereka mendekati agama Yahudi dan Kristen yang membuat sebuah kesimpulan bahwa Islam Juga termasuk agama sejarah. Pandangan ini

\footnotetext{
1 Andrew Rippin, “Analisis Sasrta Terhadap Al-Qur'an, Tafsir dan Sirrah: Metodologi John Wansbrough", dalam Richar C. Martin, Pendekatan Kajian Islam Dalam Studi Agama, tarj., (Surakarta: Muhammadiyyah University Press, 2002), hal. 201-202
} 
menuntut perlakuan sama pula terhadap sumber-sumber yang tersedia dalam kajian Islam. ${ }^{2}$ Sangat sedikit bahan-bahan yang tersedia yang dapat memberikan kesaksian yang netral untuk mengkaji islam pada masa awal, baik kuantitas data Arkeologis, bukti Numismatik, dan dokumen Historis, bukti yang terdapat diluar komunitaspun tidak banyak ditemukan, jadi untuk merekonstruksi sejarahpun menghadapi kesulitan. Menurut Rippin, Islam harus menemukan sejarahnya, namun sangat tidak mungkin merekam sejarah masa lalu, untuk itu hendaknya jangan mengabaikan kesastraan dari sumber-sumber yang ada. $^{3}$

John Wansbrough merupakan salah satu tokoh yang mencurahkan studinya mengenai pendekatan dan pengkajian tentang agama. Dalam kajiannya, ia memiliki perhatian lebih tentang teksteks kitab suci Agama. Ia memusatkan kajiannya dalam bidang sejarah teks-teks kitab suci untuk menjelaskan tentang ke-outentikan sebuah kitab suci tersebut. Wansbrough mendekati Islam dengan meneliti teks al-Qur'an yang mana ia merupakan kitab suci dan merupakan kitab yang menjadi pedoman dalam perilaku keberagamaan umat Islam.

Karena ia memiliki pandangan bahwa al-Qur'an adalah sebuah teks yang berisikan tentang sejarah penyelamatan dan merupakan hasil rekayasa umat setelah Muhammad, ia memberikan himbauan untuk menggunakan analisis Sastra dalam mendekati alQur'an. Dinama dia memberikan kesimpulan bahwa al-Qur'an

\footnotetext{
${ }^{2}$ Ibid,... hal. 202.

3 Andrew Rippin, “Analisis Sasrta Terhadap Al-Qur'an, Tafsir dan Sirrah: Metodologi John Wansbrough", dalam Richar C. Martin, Pendekatan Kajian Islam Dalam Studi Agama, tarj., (Yogyakarta: SUKA PRESS, 2001), hal. 164.
} 
bukanlah kitab suci dan merupakan hasil Plagiasi dari Bibel dan Taurat. Kesimpulan tersebut, meberikan reaksi yang berbeda-beda dari para ilmuan, di antara ilmuan yang pro adalah Andrew Rippin, dan yang Kontra di antaranya adalah Fazlur Rahman.

\section{B. Hakikat Sumber}

John Wansbrough mengupayakan cara yang sistematis untuk mengatasi problem yang muncul pada masa awal Islam. Untuk melepaskan pandangan teolog berkenaan dengan sejarah berkenaan asal-usul Islam. Dia memberikan anjuran tetang kritik terhadap sumber-sumber dari sudut pandang literer.

Al-Qur'an yang merupakan sumber utama bagi umat Islam, dan merupakan pegangan hidup serta merupakan dasar hukum utama untuk syariat karena didalamnya terdapat kaidah yang bersifat global. ${ }^{4}$ Selain itu al-Qur'an mempunyai kei'jazan dalam bahasa yang membentuknya karena ia diturukan untuk pendukung kenabian Muhammad.

Untuk mendekati sumber utama dalam Islam John Wansbrough sebagai mana dikutip oleh Andrew Rippin memusatkan tentang skeptisisnya sebagai berikut:

Poin metodologis dasar Wansbrough mempertanyakan tentang persoalan utama yang tidak biasa dipaparkan dalam kajian Islam: Apa buktinya? Apakah kita mempunyai kesaksian tentang pandangan muslim mengenahi pembentukan komunitasnya pada masa awal, sumber-sumber yang tidak mendukung?

${ }^{4}$ Muhammad Abu Zahra, Ushul Fiqh, (Jakarta: Pustaka Firdaus, 2007), hal. 121. 
Pertanyaan ini dihadapkan karena menurut Wansbrough pengkaji sumber (dalam hal ini adalah al-Qur'an) yang merupakan orang luar (bukan orang Islam), baru terdapat saat abad ke-2 Hijriyah.

Mengenahi sejarah turunnya al-Qur'an sampai pengkompilasiannya dapat dijelaskan secara singkat sebagai berikut. al-Qur' an turun secara berangsur-angsur selama 23 tahun. Pada masa penurunanya, al-Qur'an sudah ditulis di Pelepah kurma, tulang belulang dan kulit, dan masih berserakan. ${ }^{5}$ Pengkodifikasian awal terjasi pada masa khalifah Abu Bakar atas saran Umar bin Khatab, karena kegelisahan dan ketakutan dia oleh sebab banyak para Khuffadz yang meninggal saat terjadi peperangan yamamah yaitu sekitar $71 \mathrm{Khuffadz}$ pada tahun 12 Hijriyah. ${ }^{6}$ Pengkodifikasian kedua terjadi pada masa khalifah Utsman bin Affan, namun ada sedikit perbedaan antar pengkodifikasian pada zaman ini dengan zaman khalifah Abu Bakar, karena pada saat khalifah Utsman hanya dijadikan satu huruf yang berbahasa Quraisy sedangkan pada masa Abu Bakar masih berbentuk tujuh huruf. ${ }^{7}$

Al-Qur'an telah melalui tahapan-tahapan yang sangat panjang, sampai pada pemberian Harakat dan Nuqthah. Orang yang memprakarsai adanya tanda dalam tulisan adalah Abul Aswad adDuwali atas arahan dari kalifah Ali bin Abi Thalib, namun tidak dipublikasikan kepada halayak ramai. Saat itu hanya ada tanda harakat untuk memberikan penjelasan kepada umat dikarenakan terjadi kesalahan dalam pembacaan Harakat, baru setelah itu terdapat

\footnotetext{
${ }^{5}$ Menurut pengetahuan para sejarawan islam, hal ini dikarenakan saat tersebut masih terjadi penurunan al-Qur'an sehingga belum dijadikan buku.

${ }^{6}$ Manna Al-Kaththan, Pengantar Studi Ilmu Al-Qur'an, (Pustaka Al-Kautsar, 2007), hal. 158

${ }^{7}$ Ibid, ... hal. 168
} 
tanda Nuqthah untuk memberikan perbedaan kepada huruf-huruf yang mempunyai persamaan bentuk. ${ }^{8}$

Sunnah merupakan jalan yang dilalui orang-orang terdahulu yang kemudian diikuti oleh orang belakangan, sunnah diantraranya meliputi tata cara dan perilaku hidup baik terpuji maupun tercela. ${ }^{9}$ Dalam kasus ini Sunnah disini adalah Sunnah Nabawi yang disebut juga dengan Shirah, ia merupakan penguat hukum Islam yang mempunyai kedudukan yang sangat penting dalam Islam terbukti bahwa Shirah merupakan sumber kedua setelah al-Qur'an. Penulisan Shirah sebenarnya sudah terjadi pada masa nabi, akan tetapi pengkodifikasiannya mulai terjadi pada pertengahan abad kedua Hijriyyah saat pemerintahan Daulah Bani Umayah, yang diprakarsai oleh Khalifah Umar bin Abdul Aziz. ${ }^{10}$

Sedangkan penulisan tafsir secara penuh dan tersistematis dimulai pada abad ke-2, yang diawali dari penulisan tafsir oleh Ibnu Majjah (wafat 273), Ibnu Jarir At-Thabari (wafat 310), dan lainya, ${ }^{11}$ tafsir pada masa ini lebih bersifat Riwayah karena didalam kitab tersebut disandarkan kepada pendapat Sahabat, Tabi'in, Tabi'inTabi'in dan terkadang disertai pentarjihan terhadap pendapatpendapat yang diriwayatkan dan melakukan pengeluaran sejumlah hukum serta penjelasan gramatikalnya jika diperlukan.

Tafsir merupakan salah satu cabang dari hadist yang tidak bisa berdiri sendiri, dan belum mempunyai bentuk yang teratur, namun

8 Abdul Shabur Syahin, Saat al-Qur'an Butuh Dibela, (Jakarta: Erlangga, 2006), hal 142-143

${ }^{9}$ MM. Azami, Hadis Nabi: Sejarah dan pengkodifikasiannya, (Jakarta: Pustaka Firdaus, 1994), hal. 13

${ }^{10}$ Salim Ali Albahanawi, Rekayasa As-Sunnah, (Yogyakarta: Ittaqa Press, 2001), hal. 31

${ }^{11}$ Manna Al-Qaththan, Pengantar Studi,....... hal. 427 
pergerakan tafsir sudah dimulai dari masa Rasulullah. Dan pada masa sahabat yang terjadi dalam penafsiranpun bercorakkan penafsiran ayat dengan ayat, serta penafsiran dengan Riwayah yang disandarkan pada pendapat nabi, jika jauh dan tidak memungkinkan bertemu dengan rasul, diperkenankan berijtihad. ${ }^{12}$

Menurut Wansbrough semua data tersebut hanya disusun oleh orang Islam setelah pasca kenabian, dan manuskrip-manuskrip tersebut belum lengkap sepenuhnya sampai pada abad ke-3 Hijriyyah. Bukti substansial tentang manuskrippun tidak menyediakan penanggalan awal.

Pendapat Wansbrough tentang sejarah peradapan Islam masa awal, dan apa yang dijelaskan dalam sejarah pengkompilasian baik al-Qur'an, Sunnah, dan Tafsir, adalah sebagai mana dikutip oleh Andrew Rippin:

Semua korpus dokumentasi Islam masa awal harus dipandang sebagai "sejarah penyelamatan" apa yang dicoba dibuktikan oleh al-Qur'an, dan apa yang dicoba dijelaskan oleh karyakarya tafsir, shirah, dan teologi, adalah bagaimana rangkaian peristiwa dunia yang terpusat pada Muhammad diarahkan oleh tuhan. ${ }^{13}$

Menurut Rippin sejarah penyelamatan sebagai mana yang ia kutip dari Thomas L. Thompson, untuk menjelaskan kata tersebut, yang ia percaya berkaitan dengan tema tersebut adalah:

Sejarah penyelamatan bukanlah cerita sejarah mengenahi peristiwa penyelamatan yang terbuka bagi studi sejarah. Sejarah penyelamatan tidak terjadi, ia berbentuk sastra yang mempunyai konteks historisnya sendiri. ${ }^{14}$

${ }^{12}$ Ibid, ... hal. 422-425.

${ }^{13}$ Anrdrew Rippin, "Pendekatan Terhadap Islam,..... hal. 167

${ }^{14}$ Ibid. 
Berkaitan dengan istilah "sejarah penyelamatan" dalam pemikiran Kristen mempunyai makna penyelamatan terhadap jiwa manusia dari kerusakan atau kehancuran dosa, demi kehidupan abadi, yang aplikasinya berbeda dalam konteks Yahudi, yaitu bermakna tuhan mempertahankan eksistensi kelompok religio-etnik tertentu, ketika faktor-faktor politik dan sosial dapat diharapkan mendukung keberhasilanya. ${ }^{15}$ Dari pernyataan tersebut, jelas kiranya skeptisisme yang telah dijadikan pendekatan bagi Rippin dan Wansbrough.

Nampaknya Rippin setuju dengan pendapat Wansbrough bahwa Sejarah penyelamatan sampai pada kita dalam bentuk sastra dan harus didekati dengan alat yang tepat, yang menurutnya metode yang paling tepat adalah Analisi Sastra. John Wansbrough berpandangan bahwa historisitas al-Qur'an merupakan sesuatu yang mengada-ada. Dalam hal ini dapat dikatakan bahwa al-Qur'an bukanlah sumber sejarah yang otoritatif, dan tidak cukup menjadi bukti dalam mengungkap sumber dan asal-usul geneologisnya sendiri juga Islam. Skeptisisme Wansbrough ini terutama disebabkan oleh sangat sedikitnya bahan-bahan yang dapat memberikan kesaksian yang "netral" untuk mengkaji Islam pada masa awal, baik kuantitas data Arkeologis, bukti Numismatik, bahkan dokumen-dokumen yang terkait dengan Historisitas al-Qur'an. Bukti-bukti yang berasal dari sumber-sumber di luar komunitas Islam sendiri tidak cukup banyak dan upaya merekonstruksi bahan-bahan tersebut ke dalam kerangka historis menghadapi banyak kesulitan. ${ }^{16}$

\footnotetext{
${ }^{15}$ Anrdrew Rippin, "Pendekatan Terhadap Islam,..... hal. 206

${ }^{16}$ Ahmad Syauqi, "Telaah Metode Analisis Sastra John Wansbrough Terhadap Al-Quran", dalam http://perpustakaanmaalmunawwarohkembangbahu.blogspot.com/, di akses pada tanggal 16 maret 2013 .
} 
Anggapan Wansbrough yang berasumsi bahwa al-Qur'an dokumen tertulis, atau teks, bukan sebagai hafalan yang dibaca atau recitation, mengantarkan ia kepada penerapan metode Filologi yang lazim digunakan dalam penelitian Bible, seperti Historical Criticism, Form Criticism, dan Textual Criticism yang mengakibatkan anggapan bahwa al-Qur'an hanya merupakan karya sejarah, dan sekedar rekaman situasi dan refleksi budaya Arab abad 7 dan 8 Masehi. ${ }^{17}$

Wansbrough berargumen bahwa kita sebenarnya tidak tahu dan mungkin tidak akan pernah dapat mengetahui apa yang sesungguhnya terjadi, semua yang kita ketahui adalah yang diyakini oleh orang yang datang kemudian, seperti yang terekam dalam sejarah penyelamatan. ${ }^{18}$

Poin yang dipahami penulis di sini adalah bahwa Wansbrough memberikan anjuran kepada penelitian agama, hakitat sumber yang ada pada suatu agama perlu diteliti ulang dan didekati secara obyektif, jangan langsung mempercayai secara penuh terhadap manuskrip tersebut, setidaknya harus diverivikasi terlebih dahulu keabsahannya.

\section{Pendekatan John Wansbrough terhadap sumber}

Jonh Wansbrough sebagai mana dijelaskan oleh Rippin dalam artikelnya, menggunakan pendekatan skeptisisme ${ }^{19}$ untuk mendekati

${ }^{17}$ Syamsudddin Arif, Orientalis dan Diabolisme Pemikiran, (Jakarta: GIP, 2008), hal. 10

${ }^{18}$ Ibid, ... hal. 169

${ }^{19}$ Skeptisisme adalah sikap menangguhkan pertimbangan sampai analisa kritik menjadi sempurna dan segala bukti yang mungkin sudah diperoleh baca Hendro Darmawan, Kamus Ilmiyah Populel, (Yogyakarta: Bintang Cemerlang, 2010), hal. 685, hal ini sepupa dengan sifat epoche dalam pendekatan fenomenologi yaitu sikap 
islam dan al-Qur'an sebagaimana pendekatan yang di lakukan pada pendekatan injil modern sebagai ganti dari pendekatan positifisme dimasa lalu.

Bila dapat di gambarkan dalam bentuk skema triadic akan muncul seperti di bawah ini:

menangguhkan penilaian, bacaDjam'annuri, Studi Agama-Agama; Sejarah dan Pemikiran, (Yogyakarta: Pustaka Rihlah, 2003), hal. 132. 


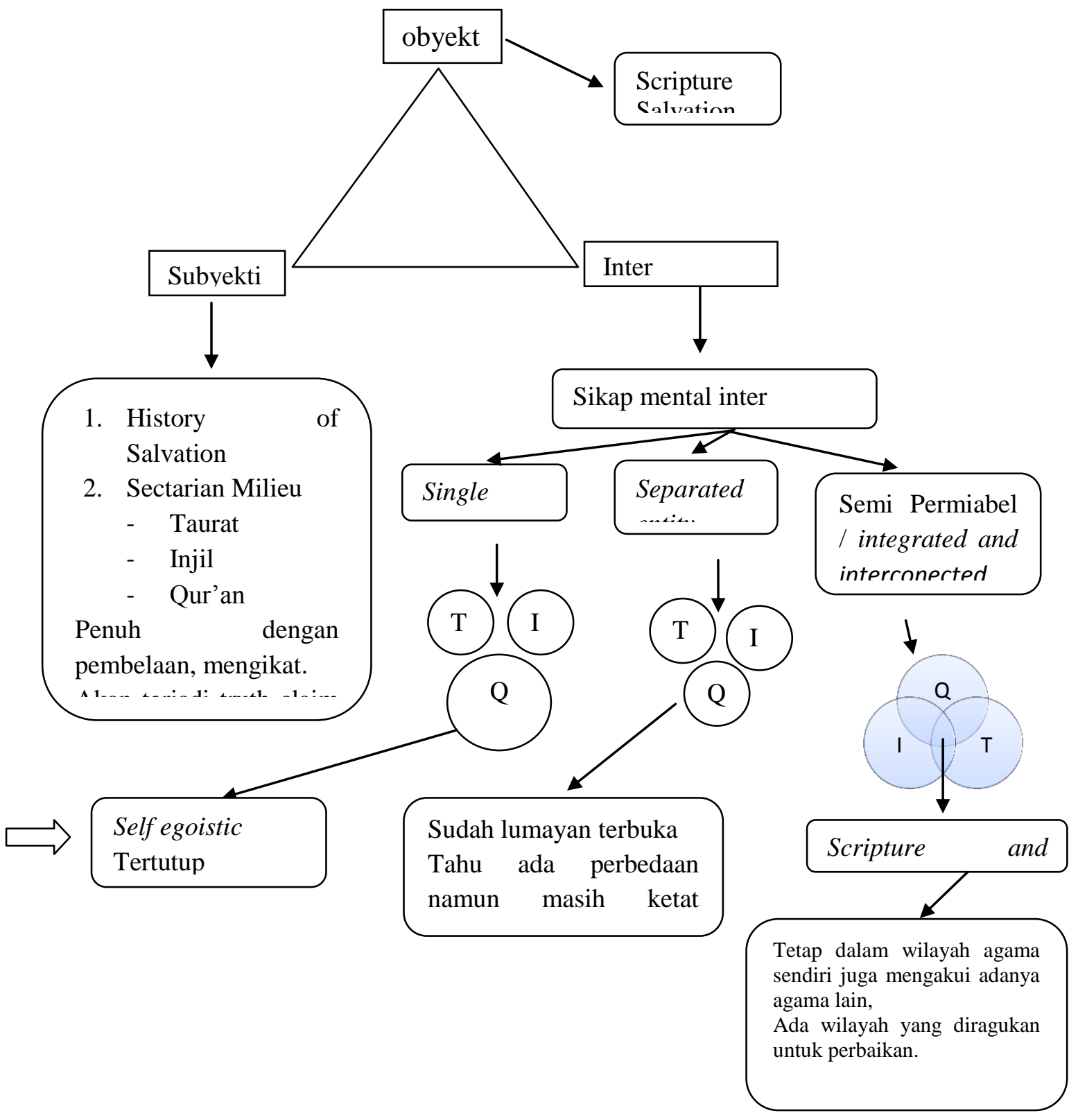

Dilihat pada skema triadic di atas, dapat disimpulkan bahwa John Wansbrough masih berkutat pada wilayah subyektif, namun tidak bisa dipungkiri bahwa dia juga memberikan sumbangan besar terhadap metodologi penelitian agama. 


\section{Metode yang digunakan John Wansbrough}

Bertolot dari skeptisisme Wansbrough mendekati Islam dan al-Qur'an dengan menggunakan bergai metode, berikut yang bisa penulis simpulkan dari metode-metode yang digunakan oleh Wansbrough adalah:

1. Metode Filologi dan Historis

Sasaran kerja Filologi adalah naskah lama, salah satu faktor yang melatar belakangi lahirnya Filologi adalah kondisi fisik dan substansi materi informasi akibat rentan waktu yang lama. Yang dimaksud dengan naskah adalah semua peninggalan tertulis pada kertas, lontar, kulit kayu, dan rotan. ${ }^{20}$

Filologi berasal dari bahasa latin yang terdiri dari dua kata philos, dan logus. Philos artinya cinta dan logos artinya kata, pembicaraan, atau ilmu. Secara harfiyah Filologi berarti cinta kepada pembicaraan atau kata-kata. Kata dipertimbangkan, dibetulkan, diperbandingkan, dijelaskan asal-usulnya, dicari variasinya, sehingga jelas bentuk dan artinya. ${ }^{21}$ Seiring dengan berjalannya waktu , pengertian Filologi berkembang yaitu tidak hanya terbatas pada penelitian tentang kritik teks dan komentar melainan berkembang kewilayah ilmu yang menyelidiki tentang kebudayaan suatu bangsa berdasarkan teks. ${ }^{22}$ Dari metode ini Wansbroug menemukan berbagai macan varian al-Qur'an dari para sahabat, mushaf Usmani, dan pasca Usmani, yang kesemuanya mempunyai perbedaan.

${ }^{20}$ M. Amin Abdullah, Metodologi Penelitian Agama, Pendekatan Multidisipliner, (Yogyakarta Lembaga Penelitian UIN SUKA, 2006), hal. 100

${ }^{21}$ Ibid,.. hal. 101

${ }^{22}$ Ibid. 
Wansbrough meneruskan metode awalnya dengan metode Historis, ia melakukan penelitian terhadap variae lectiones dan sampai pada kesimpulan bahwa keseluruhan riwayat tentang kodeks para sahabat, kodeks metropolitan (Mashahif al-Amshar), dan varian individual merupakan rekayasa para Fuqaha dan Filolog yang belakangan. ${ }^{23}$

Salah satu dari buku Wansbrough yang berjudul Qur'anic Studies: Sources and methods of criptural interpretation, menegaskan pula tentang penelitian historisnya yang mengatakan bahwa kompilasi Ustman merupakan fiksi, dan redaksi final alQur'an belum ditetapkan secara definitif sebelum abad ke-3 $\mathrm{H}^{24}$ Lebih lanjut, pendekatan Historis yang dilakukan Wansbrough tentang isi al-Qur'an menyampaikan kesimpulan bahwa terdapat kesamaan dengan kitab sebelumnya, oleh sebab itu ia mengatakan bahwa al-Qur'an dipengaruhi tradisi Yahudi dan Kristen, sehingga asal usul al-Qur'an berada sepenuhnya dalam tradisi tersebut $^{25}$. Lebih ekstrimnya doktrin ajaran Islam secara umum, bahkan ketokohan Muhammad di bangun di atas prototype kependetaan yahudi. ${ }^{26}$

Setelah melalui beberapa tahapan, Wansbrough mencoba menunjukkan cara untuk membebaskan studi al-Qur'an dari kenderungan fundamentalis terhadap kitab Injil (dalam hal ini 2005), hal. 222

Taufiq Adnan Amal, Rekontruksi Sejarah al-Qur'an, (Jakarta: Alfabeta,

${ }^{24}$ Ibid, .... Hal. 293

${ }^{25}$ M. Alfatih Suryadilaga, “ Pendekatan Historis John Wansbrough Dalam Studi al-Qur'an”, dalam Abdul Mustaqim dan Sahiron Syamsuddin, Studi al-Qur'an Kontemporer, (Yogyakarta: Tiara Wacana, 2002), hal. 216.

${ }^{26}$ MM. Al-A'zami, The History Of The Qur'anic Teks: From Revelations to Compilation, (Jakarta: GIP, 2005), hal. 341 
juga termasuk al-Qur'an), dimana gagasan tentang makna atau maksud "asli" diburu, akan tetapi menjadi tidak bermakna, Wansbrough memberikan kritikan kepada para peneliti agama, sekaligus dia juga menemukan kekurangan dalam metode Filologi, ia berucap posisis tersebut dalam tradisi keilmuan dicapai karena dua faktor yang melekat dalam metodologi sebelumnya dalam studi Islam. Yang pertama: pendekatan Historis-Filologis terhadap Islam telah terperangkap oleh konsekuensi spesialisasi yang sempit kepada sebagian penganjurnya, serta metode Filologi juga dipengaruhi oleh metode yang kedua yang didalamnya telah melahirkan stagnansi kajian Islam dalam kerangka fundamentalisnya. ${ }^{27}$

Metode kedua yaitu metode Irenic yang menurut Carles Adam betujuan menuju "penghargaan yang lebih besar atas keberagaman islam dan membantu berkembangnya sikap baru terhadapnya", telah melahirkan keengganan sebagian sarjana untuk mengikuti semua cara penyelesaian melalui pandanganpandangan dan hasil mereka. ${ }^{28}$

2. Metode Analisis Sastra

Metode analisis Sastra digunakan oleh John Wansbrough untuk menganalisis cerita-cerita yang diungkapkan dalam alQur'an. Menurutnya, adanya perbedaan cerita di dalam al-Qur'an menunjukkan adanya perpaduan tradisi di dalamnya. Pada metode ini al-Qur'an dianggap sebagai karya Sastra dan bukan mempunyai nilai transesnden. Oleh karena itu, al-Qur'an

${ }^{27}$ Richard C. Martin, "Pendekatan Terhadap Islam,..... hal. 171-172

${ }^{28}$ Ibid,... hal 172 . 
dianggap sebagai buku-buku biasa yang seseorang dengan bebas dapat memberikan penilaian. ${ }^{29}$

Metode ini merupakan importasi dari teknik-teknik kritik Bible (biblical criticsm) yang pada umumnya digunakan para sarjana Yahudi dan Kristen dalam kajian-kajian modern tentang perjanjian baru dan perjanjian lama. Kajian semacam ini berangkat dari proposisi bahwa rekaman-rekaman sastra sejarah keselamatan,meskipun menampilkan diri seakan-akan semasa dengan peristiwa yang dilukiskan, pada faktanya berasal dari periode setelah itu. ${ }^{30}$

Dalam aplikasi metode tersebut, Wansbrough menemukan bahwa al-Qur'an merupakan kreasi pasca kenabian dengan terlihatnya berbagai pengaruh Yahudi pada karakter referensialnya dan kemunculan sejumlah ayat duplikat. Dalam hal ini, audiens al-Qur'an dipandang mampu mengisi detail-detail alQur'an yang hilang dalam narasi. Akan tetapi kemudian, ketika Islam sebagai entitas yang mapan dan stabil berdasarkan struktur politiknya datang setelah ekspansi Arab keluar wilayah mereka, materi al-Qur'an menjadi jauh dari lingkungan intelektual aslinya dan membutuhkan eksplikasi tertulis eksplikasi yang tersedia dalam tafsir dan shirah. ${ }^{31}$

Sebagai contoh disini bisa dilihat bagian awal surat ke-17 di dalamnya tidak membahas tentang Isro' Nabi akan tetapi lebih membahas kepada eksodus musa dan kaumnya dari Mesir ke

${ }^{29}$ M. Alfatih Suryadilaga, “ Pendekatan Historis John Wansbrough,..... hal.

${ }^{30}$ Taufiq Adnan Amal, Rekontruksi Sejarah, ........ hal. 293.

${ }^{31}$ Richard C. Martin, "Pendekatan Terhadap Islam,..... hal. 172 
Israel. Menurut Wansbrough, penggunaan konstruksi "asra bi 'abdihi lailan....." dalam al-Qur'an semuanya berkaitan dengan eksodus Musa, dan ini terbukti dengan konteks selanjutnya yang bercerita tentang Musa serta kaumnya. Ungkapan "min al masjid al haram ila al masjid al aqsa..." dipandang Wansbrough sebagai tambahan dari masa belakangan untuk mengakomodasi episode evangelium Islam dalam teks resmi (al-Qur'an). Penambahan ini menurutnya, berada sepenuhnya di bawah pengaruh Perjanjian Lama atau Taurat. ${ }^{32}$

Pandangan tentang gaya referensial al-Qur'an juga membawa Wansbrough dalam dugaan bahwa kita sekarang ini sedang berhubungan dengan gerakan sektarian secara penuh dalam "lingkungan sektarian Yahudi-Kristen". 33

Analisis Wansbrough menyatakan bahwa al-Qur'an itu bukan sekedar "calque dari bentuk-bentuk yang mapan dari masa awal", al-Qur'an bukan hanya sekedar berusaha mereproduksi Injil dalam bahasa Arab dan menyesuaikannya untuk masyarakat Arabia. Karena satu hal, al-Qur'an tidak mengikuti motif pemenuhan yang dipandang sebagai preseden oleh Perjanjian Baru dan penggunaannya dalam Injil Ibrani. Akan tetapi lebih dari itu, karena al-Qur'an muncul dalam situasi polemik, jadi, ada upaya yang jelas untuk memisahkan al-Qur'an dari wahyu Musa melalui sarana-sarana seperti modus pewahyuan dan penekanan pada bahasa dalam al-Qur'an. ${ }^{34}$

\footnotetext{
${ }^{32}$ Taufiq Adnan Amal, Rekontruksi Sejarah, ........ hal. 294.

${ }^{33}$ Richard C. Martin, "Pendekatan Terhadap Islam,..... hal. 173

${ }^{34}$ Richard C. Martin, "Pendekatan Terhadap Islam,..... hal. 174
} 
Lebih lanjut Wansbrough menyatakan bahwa kanonisasi dan stabilisasi teks al-Qur'an terjadi bersamaan dengan pembentukan komunitas. Teks kitab suci yang final tidak ada dan belum mungkin ada secara keseluruhan sebelum kekuasaan politik terkontrol secara sepenuhnya. Sehingga pada akhir abad ke- $2 \mathrm{H} / 8 \mathrm{M}$ menjadi momen historis untuk mengumpulkan secara bersama-sama tradisi oral dan unsur-unsur liturgi sehingga melahirkan kanon kitab suci yang final dan muncul konsep aktual tentang Islam.

Menurut Wansbrough Shirah adalah kesaksian narasi dari sejarah penyelamatan Islam, yang didalamnya terelaborasi muatan 23 motif polemik tradisional sektarian Timur Dekat. Oleh karena itu, semua hadits yang menyatakan tentang himpunan al-Qur'an, dalam pandangan Wansbrough, secara historis harus dianggap sebagai informasi yang tidak dapat dipercaya. Semua informasi tersebut adalah fiktif yang punya maksud-maksud tertentu. Semua informasi tersebut, barangkali disusun oleh para fuqaha untuk menjelaskan doktrin-doktrin syariah yang tidak ditemukan di dalam teks, atau mengikut model periwayatan teks orisinal Pantekosta dan kanonisasi Kitab Suci Ibrani. Semua informasi tersebut mengasumsikan sebelumnya wujudnya standar (canon) dan karena itu, tidak bisa lebih dahulu dari abad ke- 3 Hijriah. ${ }^{35}$

Dari beberapa ilustrasi yang telah dikemukakan, tampak Wansbrough memandang transmisi al-Qur'an dari generasi pertama Islam ke generasi-enerasi berikutnya hingga menjelang munculnya

${ }^{35}$ Ahmad Syauqi, "Telaah Metode Analisis Sastra John Wansbrough Terhadap Al-Quran". 
redaksi final al-Qur'an pada abad ke-3 $\mathrm{H}$ adalah dalam cara yang sangat bebas atau cair. Kaum Muslimin dari berbagai generasi yang awal selalu berupaya menyempurnakan al-Qur'an dengan berbagai cara. Penyempurnaan ini menurutnya berada di bawah pengaruh tradisi Yahudi. Ketika terjadi pembakuan al-Qur'an, keseluruhan tradisi dari berbagai stes perkembangan umat Islam tetap dipertahankan eksistensinya dalam teks final al-Qur'an. Jadi, menurut sudut pandang ini bisa dikatakan al-Qur'an merupakan karya patungan Muhammad dan generasi-generasi awal Islam.

Dari uraian di atas, penulis mencoba menganalisa setidaknya Jonh Wansbrough mencopa mendekati Islam, pada dimensi obyektif dengan menganggap al-Qur'an sebagai Sastra biasa (Srcipture). kemudian mencoba mendekatinya dengan berbagai metode yang ia terapkan untuk mengkaji literatur Islam, dengan menerapkan pendekatan skeptisisme, kemudian dia memulai dengan metode Filologi, hingga sampai kepada Critical Historisms, dan metode analisis Sastra. Walaupun tidak bisa dipungkiri dimensi subyektifitas Wansbrough sebagai outsider, tetap ada, yaitu ketika dia mendekati Qur'an dengan menggunakan tradisi Kristen dan Yahudi, bukan dengan tradisi Arab.

Pada akhir kesimpulan dari penelitian, Wansbrough memberikan anjuran supaya mendekati sumber lewat metode analisis Sastra, dan cenderung mengesampingkan Sunnah dan Asbab alNuzul, setidaknya ia sudah memberikan sumbangan yang sangat besar bagi Dirasah Islamiyyah dalam memahami Islam secara lebih komprehensif. Setidaknya lewat metode analisis Sastra, kita juga bisa 
memberikan perhatian agak lebih untuk menemukan Islam dari tinjauan sastra yang ada dalam al-Qur'an.

\section{E. Wacana Tentang Metodologi John Wansbrough.}

Hasil penelitian yang telah dikemukakan oleh John Wansbrough memberikan reaksi yang berbeda-beda di kalangan para pengkaji yang memiliki otoritas dalam studi al-Qur'an yaitu antara pro dan kontra, baik dari kalangan orientalis sendiri maupun dari kalangan Muslim. Akan tetapi, tanpa mengurangi rasa hormat penulis bagi penelitia yang lain, penulis mencoba mengambil wacana yang dikemukakan oleh Andrew Rippin dan Fazlur Rahman yang penulis rasa cukup untuk mewakili perdebatan dalam kajian ini.

Secara umum, Andrew Rippin sependapat dengan John Wansbrough. Atas dasar pemikiran bahwa Islam adalah agama dalam sejarah, Rippin membenarkan penggunaan analisis sastra oleh Wansbrough dalam mengkritisi Al-Qur'an, sebagaimana juga dipergunakan dalam mengkritisi kitab suci Yahudi dan Nasrani. Hal ini disebabkan oleh posisi Islam yang tidak historis karena tidak ada dukungan berupa bukti ekstra literer dalam data arkeologis yang tersedia. Sumber-sumber berupa teks berbahasa Arab dari kalangan muslim sendiri, lanjut Rippin, terdiri dari literatur-literatur yang ditulis dua abad setelah fakta sejarah terjadi. ${ }^{36}$

Selanjutnya, apa yang dikemukakan Wansbrough berkaitan dengan sumber-sumber Islam masa awal, menurut Rippin, bukanlah hal yang baru. Dalam hal ini Rippin beralasan bahwa Ignaz Goldziher

${ }^{36}$ Ahmad Syauqi, "Telaah Metode Analisis Sastra John Wansbrough Terhadap Al-Quran". 
dan Yosepht Schacht telah lebih dulu menyatakan hal demikian. Keduanya memahami bahwa sabda-sabda yang disandarkan kepada Muhammad dan digunakan uintuk mendukung posisi hukum atau doktrin dalam Islam sebenarnya berasal dari periode kemudian, dari masa-masa ketika posisi hukum dan doktrin ini sedang mencari dukungan dari apa yang disebut sebagai sunnah. ${ }^{37}$

Sementara dalam menanggapi tesis-tesis John Wansbrough dan pembelaan Andrew Rippin terhadap metode dan hasil yang dicapainya, Fazlur Rahman menyatakan bahwa keampuhan metode Historis sebenarnya sudah cukup membuktikan tentang keaslian bahan-bahan Historis kaum Muslim, dan pengalihan kepada suatu metode analisa Sastra yang murni tidak diperlukan. ${ }^{38}$

Fazlur Rahman memberikan contoh tentang sebuah konsekuensi yang terjadi apabila menghilangkan sisi historis dan hanya memakai pendekatan Sastra yang menjadikan para pendukung metode Sastra tidak dapat memaknai al-Qur'an, yaitu perbedaanperbedaan tertentu dalam al-Qur'an dilihat dari kronologi periode Mekkah dan Madinah, seperti kisah perselisihan Ibrahim dengan ayahnya. Surat Maryam (19) ayat 47 (Makkiyah) mengatakan bahwa Ibrahim sementara bersahabat dengan ayahnya, ia (Ibrahim) menyatakan pada ayahnya bahwa dirinya akan terus berdoa memohonkan ampun baginya. Kemudian pada periode Madinah, ketika al-Qur'an memerintahkan kaum Muhajirin untuk melepaskan diri dari anggota keluarga dekatnya di Makkah agar tetap pagan dan terus mencela dan memusuhi Muslim. Al-Qur'an mengatakan pada

\footnotetext{
${ }^{37}$ Ibid.

${ }^{38}$ Ibid.
} 
mereka, yaitu, Ibrahim berdoa memohonkan ampun bagi ayahnya hanya karena dia pernah berjanji. Dengan kata lain, bahwa dia (Ibrahim) benar-benar telah memutuskan hubungan kekeluargaan dengannya. ${ }^{39}$

Menurut pandangan Rahman, dengan melepaskan Al-Qur'an dari sandaran historisnya dalam kehidupan Muhammad, maka salah satu tugas utama Wansbrough adalah menyandarkan secara historis di tempat yang lain. Karena keharusan relokasi historis tidak bisa dikesampingkan oleh penolakan sederhana terhadap historisitas sumber-sumber awal Islam itu sendiri. Kita harus mengetahui di mana Al-Qur'an berada dan pada kelompok atau individu mana alQur'an diturunkan. ${ }^{40}$

Fazlur Rahman juga memberikan kritik terhadap tesis Wansbrough bahwa Al-Qur'an merupakan perpaduan berbagai tradisi yang berbeda. Rahman menilai bahwa Wansbrough belum sepenuhnya memahami fenomena substitusi ayat-ayat tertentu dengan ayat-ayat lainnya. Fenomena ini diakui sendiri oleh Al-Qur'an dan dinamakan naskh (yang berarti penghapusan atau substitusi). Untuk terjadi substitusi harus ada ayat baru sebagai pengganti ayat yang lama. Inilah sebuah keharusan kronologis yang sulit dipertahankan bila Al-Qur'an hanya merupakan perpaduan serentak dari berbagai tradisi. $^{41}$

${ }^{39}$ Fazlur Rahman," Pendekatan Terhadap Islam dalam Studi Agama”, dalam Richard C. Martin, Pendekatan Terhadap Islam dalam Studi Agama, tarj., (Yogyakarta: SUKA PRESS, 2001), hal. 213

${ }^{40} \mathrm{Ibid}$. hal. xiii

${ }^{41}$ Fazlur Rahman, Tema Pokok Al-Qur'an, (Bandung: Penerbit Pustaka, 1996), 
Fazlur Rahman juga menilai bahwa Wansbrough kurang memiliki data-data historis mengenai asal-usul, sifat atau karakter, evaluasi dan personalitas-personalitas yang terlibat di dalam "tradisitradisi” tersebut. Mengenahi berbagai permasalahan yang sangat penting dalam Al-Qur'an, menurutnya, kita hanya dapat memahaminya dalam terma-terma kronologis dan bekembang dalam suatu dokumen yang tunggal. ${ }^{42}$

Mengenahi pendapat Rippin yang menyatakan "pandangan klasik" tentang sumber-sumber data Islam pada masa awal, bahwa Wansbrough bukanlah orang pertama yang mengatakanya karena Ignaz Goldziher dan Yosepht Schacht telah mendahului pada pendekatan yang berhubungan dengan kritik hadist. Menurut Fazlur Rahman, Ignaz Goldziher dan Yosepht Schacht bersandar pada metode sejarah untuk menunjukkan bahwa hadits-hadits tertentu muncul setelah hadits lainnya. Oleh karena itu, lanjut Rahman, tidak jelas logika apa yang dipakai oleh Rippin untuk menawarkan metode sejarah Goldziher dan Schacht untuk mendukung analisis sastra Wansbrough, karena metode yang terakhir bersifat arbitrer. ${ }^{43}$

Mengenai alasan Rippin tentang adanya beberapa pengkaji yang menekankan latar belakang Arab Islam dengan kontribusi Yahudi dan Kristen, Fazlur Rahman berpendapat bahwa Wansbrough telah melampau batas-batas yang dapat diterima akal dalam memandang al-Qur'an sebagai manifestasi sektarian Yahudi-Kristen sepenuhnya. Pada faktanya, di Arab sendiri

\footnotetext{
${ }^{42}$ Ibid, ... Hal. xii

${ }^{43}$ Fazlur Rahman," Pendekatan Terhadap Islam dalam Studi Agama”, hal. 212
} 
Terlepas dari perdebatan di atas, perkembangan yang terjadi menunjukkan bahwa metode analisis Sastra juga sudah diterapkan oleh sebagian pemikir Muslim. Mohammed Arkoun, misalnya, sangat menyayangkan jika di kalangan Muslim tidak mau mengikuti jejak kaum Yahudi-Kristen. Di samping itu, dia pun menyayangkan bahwa kritik-kritik filsafat tentang teks-teks suci (yang telah digunakan kepada Bibel Ibrani dan Perjanjian Baru, sekalipun tanpa menghasilkan konsekuensi negatif untuk ide wahyu) terus ditolak oleh pendapat kesarjanaan Muslim. Menurut Mohammed Arkoun, metodologi John Wansbrough, memang sesuai dengan apa yang selama ini ingin dikembangkannya, di mana intervensi ilmiah John Wansborugh cocok dengan framework yang diusulkannya. Framework tersebut memberikan prioritas kepada metode-metode analisa Sastra yang, seperti bacaan Antropologis-Historis, menggiring kepada pertanyaan-pertanyaan dan sebuah refleksi yang hasilnya akan cukup meresahkan bagi kalangan fundamentalis. metode analisis Sastra juga sudah diterapkan oleh sebagian pemikir Muslim. Salah satunya adalah Nasr Hamid Abu Zayd. ${ }^{44}$

\section{F. Simpulan}

Keberadaan Islam yang telah dipercayai sebagai salah satu agama yang masuk dalam kategori "agama dalam sejarah", menarik para ilmuan Islam dan Barat untuk mengkajinya secara mendalam. Salah satunya John Wansbrough yang ingin mengetahui Islam secara mendalam dalam rangka ketertatikan ia dengan studi agama.

${ }^{44}$ Ahmad Syauqi, "Telaah Metode Analisis Sastra John Wansbrough Terhadap 
John Wansbrough mendekati Islam memulai dengan menggunakan pendekatan Skeptisisme, bahan-bahan yang dijadikan salah satu rujukan adalah sumber-sumber Islam yang berupa teks, diantaranya adalah al-Qur'an, Shirah dan Tafsir. Sangat sedikit bukti atau kesaksian yang netral pada masa awal Pembentukan Islam sehingga Wansbrough sampai pada suatu kesimpulan yaitu semua korpus dokumentasi Islam Masa awal dipandang sebagai sejarah penyelamatan.

Untuk itu, Wansbrough memberikan tekanan pada analisis Sastra dengan mengesampingkan data Historis, karena menurutnya metode tersebut merupakan metode yang sangat cocok dan netral untuk memberikan data yang obyektif tentang Islam yang menurutnya Islam sangat butuh untuk menemukan sejarahnya yang hilang. Akan tetapi dari hasil analisisnya yang mnghasilkan bahwa alQur'an merupakan duplikasi dari Kitab sebelumya, dan Islam terjebak dengan sektarian Kristen dan yahudi menimbulkan banyak tanggapan dari sarjana Barat dan Islam sendiri. 


\section{DAFTAR PUSTAKA}

Abdullah, M. Amin, Metodologi Penelitian Agama, Pendekatan Multidisipliner, Yogyakarta: Lembaga Penelitian UIN SUKA, 2006.

Al-A'zami, The History Of The Qur'anic Teks: From Revelations to Compilation, Jakarta: GIP, 2005.

Albahanawi, Salim Ali, Rekayasa As-Sunnah, Yogyakarta: Ittaqa Press, 2001.

Al-Kaththan, Manna, Pengantar Studi Ilmu Al-Qur'an, Pustaka AlKautsar, 2007.

Amal, Taufiq Adnan, Rekontruksi Sejarah al-Qur'an, Jakarta: Alfabeta, 2005.

Arif, Syamsudddin, Orientalis dan Diabolisme Pemikiran, Jakarta: GIP, 2008.

Azami, Hadis Nabi: Sejarah dan pengkodifikasiannya, Jakarta: Pustaka Firdaus, 1994.

Darmawan, Hendro, Kamus Ilmiyah Populel, Yogyakarta: Bintang Cemerlang, 2010.

Djam'annuri, Studi Agama-Agama; Sejarah dan Pemikiran, Yogyakarta: Pustaka Rihlah, 2003.

Rahman, Fazlur, Tema Pokok Al-Qur'an, Bandung: Penerbit Pustaka, 1996.

," Pendekatan Terhadap Islam dalam Studi Agama", dalam Richard C. Martin, Pendekatan Terhadap Islam dalam Studi Agama, tarj., Yogyakarta: SUKA PRESS, 2001.

Rippin, Andrew, “Analisis Sasrta Terhadap Al-Qur'an, Tafsir dan Sirrah: Metodologi John Wansbrough", dalam Richar C. Martin, 
Pendekatan Kajian Islam Dalam Studi Agama, tarj., Surakarta: Muhammadiyyah University Press, 2002.

, “Analisis Sasrta Terhadap Al-Qur'an, Tafsir dan Sirrah: Metodologi John Wansbrough", dalam Richar C. Martin, Pendekatan Kajian Islam Dalam Studi Agama, tarj., Yogyakarta: SUKA PRESS, 2001.

Suryadilaga, M. Alfatih, “ Pendekatan Historis John Wansbrough Dalam Studi al-Qur'an", dalam Abdul Mustaqim dan Sahiron Syamsuddin, Studi al-Qur'an Kontemporer, Yogyakarta: Tiara Wacana, 2002.

Syahin, Abdul Shabur, Saat al-Qur'an Butuh Dibela, Jakarta: Erlangga, 2006.

Syauqi, Ahmad, "Telaah Metode Analisis Sastra John Wansbrough Terhadap Al-Quran", dalam http:// perpustakaan ma almunawwaroh kembangbahu.blogspot.com/.

Zahra, Muhammad Abu, Ushul Fiqh, Jakarta: Pustaka Firdaus, 2007. 